\title{
Article \\ Endocrine-Disrupting Organochlorine Pesticides in Human Breast Milk: Changes during Lactation
}

\author{
Agata Witczak ${ }^{1, *(\mathbb{D})}$, Anna Pohoryło ${ }^{1}$ and Hassan Abdel-Gawad ${ }^{2} \mathbb{D}$ \\ 1 Department of Toxicology, Dairy Technology and Food Storage, Faculty of Food Sciences and Fisheries, \\ West Pomeranian University of Technology in Szczecin, 71-459 Szczecin, Poland; annapohorylo@wp.pl \\ 2 Applied Organic Chemistry Department, Chemical Industries Research Division, National Research Centre, \\ Dokki, Giza 12622, Egypt; abdelgawadhassan@hotmail.com \\ * Correspondence: agata.witczak@zut.edu.pl
}

Citation: Witczak, A.; Pohoryło, A.; Abdel-Gawad, $\mathrm{H}$.

Endocrine-Disrupting

Organochlorine Pesticides in Human Breast Milk: Changes during

Lactation. Nutrients 2021, 13, 229.

https://doi.org/10.3390/nu13010229

Received: 1 December 2020

Accepted: 11 January 2021

Published: 14 January 2021

Publisher's Note: MDPI stays neutral with regard to jurisdictional clai$\mathrm{ms}$ in published maps and institutional affiliations.

Copyright: $\odot 2021$ by the authors. Licensee MDPI, Basel, Switzerland. This article is an open access article distributed under the terms and conditions of the Creative Commons Attribution (CC BY) license (https:// creativecommons.org/licenses/by/ $4.0 /)$.

\begin{abstract}
The aim of the present study was to assess infant safety associated with the occurrence of endocrine-disrupting organochlorine pesticides (OCP) in breast milk. Moreover, the association between pregnant mothers' dietary habits and these compounds levels in breast milk was investigated. Breast milk was collected at various stages of lactation. The samples were analyzed by the GC-MS method. The OCP concentrations ranged from < limit of detection (LOD) to $6.81 \mathrm{ng} / \mathrm{g}$ lipids. The highest OCP concentrations in breast milk occurred primarily within the first month of lactation, and decreased over the lactation period. It was found that the maternal consumption of certain food products-in particular pork, beef, poultry, eggs, and dairy products—could have affected the content of 1,1'-(2,2,2-Trichloroethane-1,1-diyl)bis(4-chlorobenzene), called DDT and its metabolites in the breast milk. The levels of beta-endosulfan were positively correlated with fish and poultry consumption. The redundancy analysis indicated that the diets of the pregnant women had an important impact on pesticide residues in the breast milk. There is a potential possibility of lowering the content of organochlorine compounds in breast milk by adhering to nutritional recommendations, e.g., avoiding the excessive consumption of fish and other raw food materials of unknown origin.
\end{abstract}

Keywords: human breast milk; OCPs; infant health; lactation; endocrine disrupting pesticides

\section{Introduction}

Breast milk is the first food that humans consume, from birth to a recommended minimum of six months, and it provides all of the necessary nutrients [1]. Breastfeeding is highly beneficial, but breast milk can also transmit endocrine-disrupting organochlorine pesticide (OCP) residues from the mother to the infant [2]. OCPs are characterized by semivolatility, high environmental persistence, a long half-life, and a high degree of lipophilicity. These properties contribute to adverse effects on human health; among others, this includes endocrine disruption and reproductive toxicity. Long-term exposure to OCP can lead to a variety of endocrine and reproductive disorders, including gonadal changes, changes in reproductive behavior, reduced sperm quality, an increase in organ malformations (e.g., hypospadias), testicular failure (kryptorchim), fetal defects, thyroid dysfunction, and more. The level of thyroid hormones in the prenatal period influences, among others, the proper development and functioning of the peripheral nervous system and the brain. Worryingly, endocrine disrupting compounds (EDCs) can disrupt human endocrine function at very low levels of exposure. It is suspected that EDCs also contribute to the increased incidence of cervical tumors, tumors of the mammary gland and testes, behavioral changes, reduced IQ, and permanent liver and kidney damage. OCPs can act as neurotoxins that block the activity of inhibitory neurotransmitters. They also impair immune functions [3,4]. Organochlorine pesticides (OCPs) have been reported to be associated with an elevated risk of type 2 diabetes in a Chinese population [5]. 
Infant exposure to OCPs starts in the prenatal period, because of transfusion through the placenta. After birth, OCP exposure continues via lactation. These compounds are accumulated in the mammary glands, and are secreted along with breast milk due to the lipophilicity of OCPs. The increased health risks to infants stem mainly from their incompletely-formed detoxification mechanisms, and the high sensitivity of young organisms. These substances show the ability to penetrate various body barriers, including the blood-placenta barrier, which poses a threat in the prenatal period, increasing the risk of developmental defects. Infants are exposed to high levels of OCPs because of higher food consumption in relation to body weight, that is, several times that of adults $[6,7]$.

Exposure in the postnatal period is also important in terms of the intensive development of organs, e.g., the brain. During the first 90 days of life, the infant develops intensively, and its brain increases in volume by about $64 \%$. Considering the above, EDCs may pose a significant public health risk.

Pregnant women are exposed to these compounds mainly through dietary intake [8], particularly from fish, meat, and milk $[9,10]$.

Despite the decades-long worldwide ban on the use of OCPs, residues are still being found in breast milk all over the world [11-14]. Since the 1970s, the use of OCPs has been prohibited in Poland due to their high persistence in the environment, toxicity, and ability to accumulate in the food chain of humans and other living organisms. For example, the withdrawal of products with DDT began in Poland in 1976. Organochlorine pesticides—such as DDT, hexachlorocyclohexane $(\mathrm{HCH})$, aldrin, endrin, heptachlor, and hexachlorobenzene (HCB)-have been included in the group of so-called persistent organic pollutants (POPs) due to the Stockholm Convention [15].

Human breast milk is an ideal marker for OCPs, as it provides information on the exposure of mothers and newborns to the toxic effects of these compounds. The accumulation of organochlorine compounds in breast milk can be influenced by many different factors, such as diet, place of residence, smoking, maternal age and weight, and the duration of previous lactation; however, the literature provides divergent information [16].

Therefore, the main purpose of this study was to assess infant safety regarding the content of selected persistent organochlorine pesticides (OCPs) in breast milk during lactation periods. The interest of this study was also the influence of the pregnant mother's diet on the OCP levels in human breast milk. Correlations were sought between the content of the compounds analyzed and maternal age and body weight, the number of births, the duration of lactation, and the dietary habits of the pregnant women. Based on the surveys conducted, the impact was estimated of the frequency of the consumption of selected food products during pregnancy on the level of pesticides in breast milk.

\section{Materials and Methods}

\subsection{Participants and the Biological Material Tested}

The study participants were 96 mothers, aged 18-36, residing in northwestern Poland. None of the participants had had any previous contact with hazardous chemical compounds at work or in their places of residence. The studies did not include women with contraindications to breastfeeding on the part of the mother or infant, e.g., a severe childhood illness that makes it impossible for the mother to take care of the child, maternal cytotoxic chemotherapy, active maternal tuberculosis, or high-dose alcohol consumption by the mother, etc.

The study was conducted from 2013 to 2015 (a total of 920 samples). The Bioethics Commission at the District Chamber of Physicians in Szczecin consented to the study being conducted (consent of Bioethics Commission No OIL-Sz/MF/KB/452/02/04/2015 of 23 April 2015).

A questionnaire survey was conducted in order to collect the following information about the mothers and their infants: maternal age, number of births, maternal body weight prior to and after pregnancy, infant's body weight at birth, place of residence, education, and smoking (Table 1). The results from the questionnaire on the basic eating habits of the 
mothers participating in the study are presented in Table 2. All of the mothers gave the requested information.

Table 1. Characteristics of the pregnant women participating in the study $\left(n^{a}=96,920\right.$ samples of milk).

\begin{tabular}{|c|c|c|c|}
\hline No. & $\begin{array}{l}\text { Basic Information on } \\
\text { Mother and Child }\end{array}$ & $\begin{array}{l}\text { Response Given in } \\
\text { Questionaire }\end{array}$ & $\begin{array}{l}\text { Percentage of Given } \\
\text { Responses }(\%)\end{array}$ \\
\hline \multirow{6}{*}{1.} & \multirow{6}{*}{ mother's age [years] } & $<18$ & $4.2(\%)$ \\
\hline & & $18-22$ & - \\
\hline & & $23-27$ & $25(\%)$ \\
\hline & & $28-32$ & $37.5(\%)$ \\
\hline & & $33-36$ & $33.3(\%)$ \\
\hline & & $>36$ & - \\
\hline \multirow{4}{*}{2.} & \multirow{4}{*}{$\begin{array}{l}\text { body weight prior } \\
\text { pregnancy }[\mathrm{kg}]\end{array}$} & $<55$ & $25(\%)$ \\
\hline & & $56-60$ & $12.5(\%)$ \\
\hline & & $61-65$ & $20.8(\%)$ \\
\hline & & $>65$ & $41.7(\%)$ \\
\hline \multirow{4}{*}{3.} & \multirow{4}{*}{$\begin{array}{l}\text { body weight in the first week } \\
\text { after the childbirth [kg] }\end{array}$} & $55-60$ & $20.8(\%)$ \\
\hline & & $61-65$ & $20.8(\%)$ \\
\hline & & $66-70$ & $25(\%)$ \\
\hline & & $>70$ & $33.4(\%)$ \\
\hline \multirow{3}{*}{4.} & \multirow{3}{*}{ place of residence } & city $>5.000$ inhabitants & $83.3(\%)$ \\
\hline & & town $<5.000$ inhabitants & $4.2(\%)$ \\
\hline & & Country & $12.5(\%)$ \\
\hline \multirow{3}{*}{5.} & \multirow{3}{*}{ education } & Primary & $4.2(\%)$ \\
\hline & & Secondary & - \\
\hline & & Higher & $95.8(\%)$ \\
\hline \multirow{4}{*}{6.} & \multirow{4}{*}{ number of given childbirths } & 1 & $62.5(\%)$ \\
\hline & & $2-3$ & $37.5(\%)$ \\
\hline & & $4-5$ & - \\
\hline & & $>5$ & - \\
\hline \multirow{2}{*}{7.} & \multirow{2}{*}{ type of birth } & natural forces & $50(\%)$ \\
\hline & & C-section & $50(\%)$ \\
\hline \multirow{2}{*}{8.} & \multirow{2}{*}{ infant's sex } & Boy & $62.5(\%)$ \\
\hline & & girl & $37.5(\%)$ \\
\hline \multirow{5}{*}{9.} & \multirow{5}{*}{$\begin{array}{l}\text { infant's body weight in the } \\
\text { first week }[\mathrm{kg}]\end{array}$} & $2.4-2.8$ & $4.2(\%)$ \\
\hline & & $2.9-3.2$ & $45.8(\%)$ \\
\hline & & $3.3-3.6$ & $45.8(\%)$ \\
\hline & & $3.7-4.0$ & - \\
\hline & & $>4.0$ & $4.2(\%)$ \\
\hline \multirow{7}{*}{10.} & \multirow{7}{*}{ smoking } & never smoked & $75(\%)$ \\
\hline & & $\begin{array}{l}\text { quitted before pregnancy } \\
\text { used to smoke (number } \\
\text { of packs á } 20 \text { cigarettes) }\end{array}$ & $16.7(\%)$ \\
\hline & & $>\quad$ up to one a day & $4.2(\%)$ \\
\hline & & $>\quad$ more than one a day & $4.2(\%)$ \\
\hline & & $\begin{array}{l}\text { smokes at present } \\
\text { (number of packs) }\end{array}$ & \\
\hline & & up to one a day & - \\
\hline & & more than one a day & - \\
\hline
\end{tabular}


Table 2. Eating habits of the pregnant women based on the survey.

\begin{tabular}{|c|c|c|c|c|c|c|c|}
\hline \multirow{2}{*}{\multicolumn{2}{|c|}{ Product }} & Never & $\begin{array}{c}\text { Less that Once } \\
\text { a Week }\end{array}$ & $\begin{array}{l}\text { Once a } \\
\text { Week }\end{array}$ & $\begin{array}{l}\text { Twice } \\
\text { a Week }\end{array}$ & $\begin{array}{c}\text { More Than Twice } \\
\text { a Week }\end{array}$ & $\begin{array}{c}\text { Every } \\
\text { Day }\end{array}$ \\
\hline & & \multicolumn{6}{|c|}{ Percentage of Responses [\%] } \\
\hline \multirow{2}{*}{\multicolumn{2}{|c|}{$\begin{array}{c}\text { Fish } \\
\text { Dairy products }\end{array}$}} & 4.2 & 37.5 & 29.2 & 12.5 & 16.6 & - \\
\hline & & 12.5 & - & - & - & 25 & 62.5 \\
\hline \multirow{2}{*}{ Meat } & beef & 16.7 & 58.3 & 8.3 & 12.5 & 4.2 & - \\
\hline & pork & - & 8.4 & 20.8 & 33.3 & 37.5 & - \\
\hline \multirow{3}{*}{\multicolumn{2}{|c|}{$\begin{array}{c}\text { Poultry } \\
\text { Eggs } \\
\text { Fruit }\end{array}$}} & - & - & 8.3 & 16.7 & 70.8 & 4.2 \\
\hline & & - & 29.1 & 12.5 & 12.5 & 41.7 & 4.2 \\
\hline & & - & - & 4.2 & 4.2 & 16.6 & 75 \\
\hline \multicolumn{2}{|c|}{ Vegetables } & - & - & - & 4.2 & 8.3 & 87.5 \\
\hline \multirow{6}{*}{ 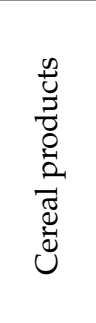 } & groats & - & 50 & 25 & 20.8 & 4.2 & - \\
\hline & rice & - & 37.5 & 50 & 12.5 & - & - \\
\hline & pasta & - & 29.2 & 41.6 & 29.2 & - & - \\
\hline & $\begin{array}{l}\text { Whole } \\
\text { meal } \\
\text { bread }\end{array}$ & 8.3 & 16.7 & 16.7 & 8.3 & 20.8 & 29.2 \\
\hline & $\begin{array}{l}\text { wheat } \\
\text { bread }\end{array}$ & 8.3 & 12.5 & 12.5 & 8.3 & 25 & 33.4 \\
\hline & $\begin{array}{l}\text { mixed } \\
\text { bread }\end{array}$ & 12.5 & 25 & 20.8 & 8.3 & 29.2 & 4.2 \\
\hline
\end{tabular}

Prior to participating in the study, each mother gave written consent for milk collection. Additionally, each participant was informed about the course of the experiment.

The study material analyzed was breast milk. The samples were collected during various lactation periods, ranging from the first to the twelfth month after childbirth. The milk was expressed with breast pumps after the participants had washed their breasts and hands with soap and water [16,17].

All of the mothers were supplied with glass bottles that had been rinsed first with hexane and methanol used for chromatography analysis. The mothers poured the breast milk samples, measuring from 40 to $100 \mathrm{~mL}$, from the breast pumps directly into the glass bottles. The bottles were closed using caps, which were additionally secured inside with aluminum foil. The milk samples were stored at $-18{ }^{\circ} \mathrm{C}$ in glass bottles in a home freezer until transport to the laboratory.

The milk sampling schedule was the duration of lactation, from the first day after birth to 12 months or more. In the first month of lactation, samples were collected from the mothers weekly, i.e., on days 7, 14, 21, and 28 after delivery. In the following months, the collected milk was the average sample of 4 samples at the end of each month. Each of the mothers participating in the study received precise guidelines on how and when to take the milk. Additionally, each of the mothers was asked to describe the exact time of the milk collection. The more frequent collection of milk in the first month of lactation, compared to the remaining periods, was due to the assumption that there may be the greatest changes in the content of OCPs during this time.

\subsection{Chemical Materials—Reagents}

The reagents (e.g., anhydrous sodium sulfate, hexane, acetone) used for the chromatographic analysis were obtained from Merck.

Standard solutions of the compounds tested were obtained from the following companies:

a) Supelco, USA-4S8913, SS TCL Pesticides;

b) Supelco, USA-N11480 internal standard;

c) Community Bureau of Reference, Belgium-Reference Material BCR 450-PCBs in natural milk powder. 


\subsection{Analytical Methodology}

After transport to the laboratory, each sample was labeled with the necessary information regarding the mother and her infant, covered with aluminum foil, and frozen. The samples were homogenized and freeze dried at $-60^{\circ} \mathrm{C}$ in a LYOLAB 3000 freeze dryer. The lyophilized samples were frozen at $-18^{\circ} \mathrm{C}$ and stored until the analysis.

The sample preparation included Soxhlet extraction and qualitative and quantitative analyses with gas chromatography-mass spectrometry (GCMS) according to Witczak et al. [18]. The analyses of organochlorine pesticides (aldrin, dieldrin, endrin, alpha-endosulfan, betaendosulfan, endosulfan sulphate, heptachlor, heptachlor epoxide isomer B and methoxychlor, endrin ketone, endrin, dichlorodiphenyldichloroethylene ( $\mathrm{pp}^{\prime}$-DDE), dichlorodiphenyldichloro ethane (pp'-DDD), $\mathrm{pp}^{\prime}-\mathrm{DDT}, \alpha-\mathrm{HCH}, \beta-\mathrm{HCH}, \gamma-\mathrm{HCH}$, and $\delta-\mathrm{HCH}$ ) were performed in three replicates using the following gas chromatograph/ mass spectrometer (GC/MS) settings: carrier gas-helium; pressure- $0.061 \mathrm{MPa}(8.9 \mathrm{psi})$; flowrate $-0.8 \mathrm{~mL} \mathrm{~min}^{-1}$; column (HP-5MS/60.0 m; ID $250 \mu \mathrm{m}, 2.25 \mu \mathrm{m}$ film thickness of the active phase); oven temperaturestart from $90^{\circ} \mathrm{C}(0.5 \mathrm{~min})$, increase $7^{\circ} \mathrm{C} \mathrm{min}^{-1}, 220^{\circ} \mathrm{C}(12 \mathrm{~min})$, increase $6{ }^{\circ} \mathrm{C} \min ^{-1}, 285^{\circ} \mathrm{C}$ (7 min), increase $5^{\circ} \mathrm{C} \mathrm{min}-1,295^{\circ} \mathrm{C}(6 \mathrm{~min})$ (post run). The analysis time of one sample was $54.9 \mathrm{~min}$. The detector was a HP 5973 mass spectrometer.

\subsection{Quality Control}

The procedure was evaluated according to Witczak [18]. The monitoring compound recovery, identification, and quantification was based on the following standard solutions: SS TCL Pesticides, Supelco, Bellefonte USA, 4S8913 (aldrin, dieldrin, endrin, alpha-endosulfan, beta-endosulfan, endosulfan sulphate, heptachlor, heptachlor epoxide isomer $\mathrm{B}$, methoxychlor, endrin ketone, endrin, $\mathrm{pp}^{\prime}-\mathrm{DDE}, \mathrm{pp}^{\prime}$-DDD, $\mathrm{pp}^{\prime}$-DDT, $\alpha-\mathrm{HCH}, \beta-\mathrm{HCH}, \gamma-\mathrm{HCH}$ and $\delta-\mathrm{HCH}$ ), and an internal standard (cis-chlordane, $80 \mathrm{ng} \mathrm{mL}^{-1}, \mathrm{~N} 11480-10 \mathrm{MG}$, Supelco, USA). The limit of detection (LOD) for each compound was determined according to Commission Directive 2002/63/EC [19]. A blank method was included for every ten samples. The limit of detection (LOD) for each of the compounds tested was $0.01 \mathrm{ng} \mathrm{mL}^{-1}$ on average.

The limits of quantitation $(L O Q)$ were estimated as (1)

$$
L O Q=10 \cdot S
$$

where $S$ is the standard deviation of ten independent measurements of the blank sample.

The LOQs varied depending on the pesticide: $\alpha-, \beta-, \gamma-\mathrm{HCH}-0.04 \mathrm{ng} \mathrm{mL}^{-1} ; \mathrm{pp}^{\prime}$ DDE-0.06 $\mathrm{ng} \mathrm{mL}^{-1}$; $\mathrm{pp}^{\prime}$-DDD—0.05 $\mathrm{ng} \mathrm{mL}^{-1}$; $\mathrm{pp}^{\prime}$-DDT—0.01 $\mathrm{ng} \mathrm{mL}^{-1}$; dieldrin, aldrin, heptachlor epoxide- $0.06 \mathrm{ng} \mathrm{mL}^{-1}$; endrin $-0.3 \mathrm{ng} \mathrm{mL}^{-1}$; endrin aldehyde, methoxychlor$0.05 \mathrm{ng} \mathrm{mL}^{-1}$; heptachlor- $0.4 \mathrm{ng} \mathrm{mL}^{-1}$; alpha-, beta-endosulfan, endosulfan sulfate, and endrin ketone $-0.08 \mathrm{ng} \mathrm{mL}-1$. The average recovery of the organochlorine pesticides ranged from 69.9 to $101.3 \%$ [18].

\subsection{Assessment of Infant Exposure Risk}

The infant exposure risk was estimated based on the lifetime average daily dose (LADD) and the hazard quotient (HQ) ([20-22], taking into account milk consumption, infant body weight, infant sex, and the estimated food intake. Daily milk consumption ranges from $478 \mathrm{~mL}$ to $1356 \mathrm{~mL}$, with an average of $798 \mathrm{~mL}$ [23-25].

In order to assess the health risk, a lifetime average daily dose (LADD) and hazard quotient (HQ) for the pesticides were calculated. The following Equations (2) and (3) were used to estimate the $L A D D$ and $H Q$ :

$$
L A D D\left(m g \cdot \mathrm{kg}^{-1} \cdot \mathrm{d}^{-1}\right)=\frac{C\left(m g \cdot g^{-1}\right) \cdot C R\left(g \cdot d^{-1}\right)}{B W(k g)}
$$


where $L A D D$ is the daily dosage during life; $C$ is the average concentration of the pesticide in human milk, $C R$ is the average daily milk consumption, and $B W$ is the average body weight in $\mathrm{kg}$.

$$
H Q=\frac{L A D D}{R f D}
$$

where $R f D$ is the reference dose $\left(m g \cdot \mathrm{kg}^{-1} \cdot \mathrm{d}^{-1}\right)$.

An $H Q$ value exceeding 1.0 indicates that it is harmful to human health.

\subsection{Statistical Analysis}

The results obtained were analyzed using Statistica 13.0. ANOVA; the analysis of variance was preceded by Levene's homogeneity test and the Kolmogorov-Smirnov normality test (K-S test). The results were expressed as arithmetic means with standard deviations (SD) and coefficients of variations (CV). The Pearson correlation coefficient was estimated in order to reflect the relations among the collection time; maternal age; number of births; maternal body weight prior to and after pregnancy; and the milk contents of lipids, protein, lactose, dry matter, and OCPs. Different milk collection times were also taken into account. Guilford's rule of thumb [26] was used to determine the strength of the relationships. Tukey's range test $(p<0.05)$ was used to find mean values that were significantly different.

Ordination methods were applied to reveal whether the changes in the OCP contents were driven by the independent variables. Ordination is a noise-reduction technique [27]. This type of statistical analysis was used because the data set included multiple dependent and independent variables. The set of many variables can be reduced to lowdimensional space.

In this study, redundancy among the predictors was explored with the variance inflation factor (VIF) in canonical correspondence analysis (CCA) [28,29]. Detrended correspondence analysis (DCA) was applied for the dependent variables, and the gradient of the DCA first axis was determined. A redundancy analysis (RDA) on monotonic responses was performed based on this [30-32]. A permutation test to assess the significance of consecutive axes was used. The RDA analysis was performed according to The R Project for Statistical Computing [33].

\section{Results}

\subsection{Characteristics of the Study Participants}

The characteristics of the study participants are presented in Table 1. Most of the study participants were women aged 28-32 and 33-36 (Table 1).

\subsection{Composition of Breast Milk during Lactation}

Decreases in the breast milk content of dry matter, lipids, and protein over the lactation period were observed (Table 3$)$, with negative $r$ correlations $(p<0.05)$ of $-0.42,-0.38$, and -0.50 , respectively (Table 3 ). 
Table 3. Mean content of the basic composition of breast milk (number of samples $n=920$ ).

\begin{tabular}{cccccc}
\hline Lactation Period & Number of Samples & Protein [\%] & Lactose [\%] & Dry Matter [\%] & Lipid [\%] \\
\hline$<$ days & $17^{\mathrm{a}}$ [\% & $1.49 \pm 0.23 \mathrm{~b}$ & $5.33 \pm 0.30$ & $15.34 \pm 0.00$ & $3.92 \pm 0.00$ \\
7 days & 26 & $1.48 \pm 0.18$ & $7.27 \pm 0.47$ & $13.21 \pm 1.38$ & $4.60 \pm 0.77$ \\
14 days & 59 & $1.28 \pm 0.26$ & $6.90 \pm 0.24$ & $12.71 \pm 0.79$ & $4.34 \pm 0.59$ \\
21 days & 98 & $1.18 \pm 0.24$ & $6.77 \pm 0.29$ & $12.12 \pm 1.05$ & $4.13 \pm 0.63$ \\
28 days & 39 & $1.07 \pm 0.30$ & $6.98 \pm 0.68$ & $12.54 \pm 0.56$ & $3.48 \pm 0.36$ \\
2nd month & 75 & $1.12 \pm 0.24$ & $6.87 \pm 0.34$ & $12.50 \pm 1.41$ & $4.22 \pm 0.86$ \\
3rd month & 75 & $1.07 \pm 0.21$ & $6.81 \pm 0.32$ & $12.04 \pm 1.32$ & $3.85 \pm 0.76$ \\
4th month & 92 & $1.08 \pm 0.22$ & $6.83 \pm 0.34$ & $12.08 \pm 1.86$ & $3.90 \pm 0.77$ \\
5th month & 88 & $1.11 \pm 0.28$ & $6.84 \pm 0.25$ & $12.04 \pm 1.74$ & $3.73 \pm 0.88$ \\
6th month & 88 & $1.07 \pm 0.25$ & $6.66 \pm 0.27$ & $11.36 \pm 1.36$ & $3.67 \pm 0.90$ \\
7th month & 69 & $1.19 \pm 0.25$ & $6.84 \pm 0.33$ & $12.36 \pm 1.95$ & $4.18 \pm 0.89$ \\
8th month & 39 & $0.99 \pm 0.06$ & $6.92 \pm 0.26$ & $13.52 \pm 1.70$ & $4.10 \pm 0.60$ \\
9th month & 29 & $1.08 \pm 0.15$ & $6.85 \pm 0.30$ & $12.36 \pm 0.88$ & $4.22 \pm 0.23$ \\
10th month & 29 & $0.93 \pm 0.04$ & $6.62 \pm 0.43$ & $10.57 \pm 0.58$ & $3.83 \pm 0.47$ \\
11th month & 29 & $0.84 \pm 0.06$ & $6.54 \pm 0.25$ & $10.44 \pm 0.57$ & $3.49 \pm 0.03$ \\
12th month & 29 & $0.88 \pm 0.03$ & $6.45 \pm 0.08$ & $8.66 \pm 0.25$ & $3.14 \pm 0.02$ \\
>year of breast & 39 & & & & $2.37 \pm 0.17$ \\
feeding & & $1.12 \pm 0.18$ & $6.73 \pm 0.30$ & $11.99 \pm 1.09$ & $3.83 \pm 0.52$ \\
\hline mean content & & &
\end{tabular}

${ }^{a}$ Each sample was analyzed in triplicate analytical duplicates; ${ }^{b}$ arithmetic average \pm standard deviation.

\subsection{OCP Residues in Breast Milk}

Residues of organochlorine pesticides were detected in most of the milk samples (Tables 4 and 5).

The concentrations of OCPs noted were low, in the range of $<\mathrm{LOQ}$ to $7.5 \mathrm{ng} / \mathrm{g}$ lipids. The content of most of the compounds tested decreased throughout the duration of lactation, and a weak negative correlation was noted (Figures 1 and 2). The highest OCP concentrations were usually noted in the breast milk collected in the first month of lactation (Tables 4 and 5). The analysis of the relationship between the OCP levels and the duration of lactation revealed a negative correlation.
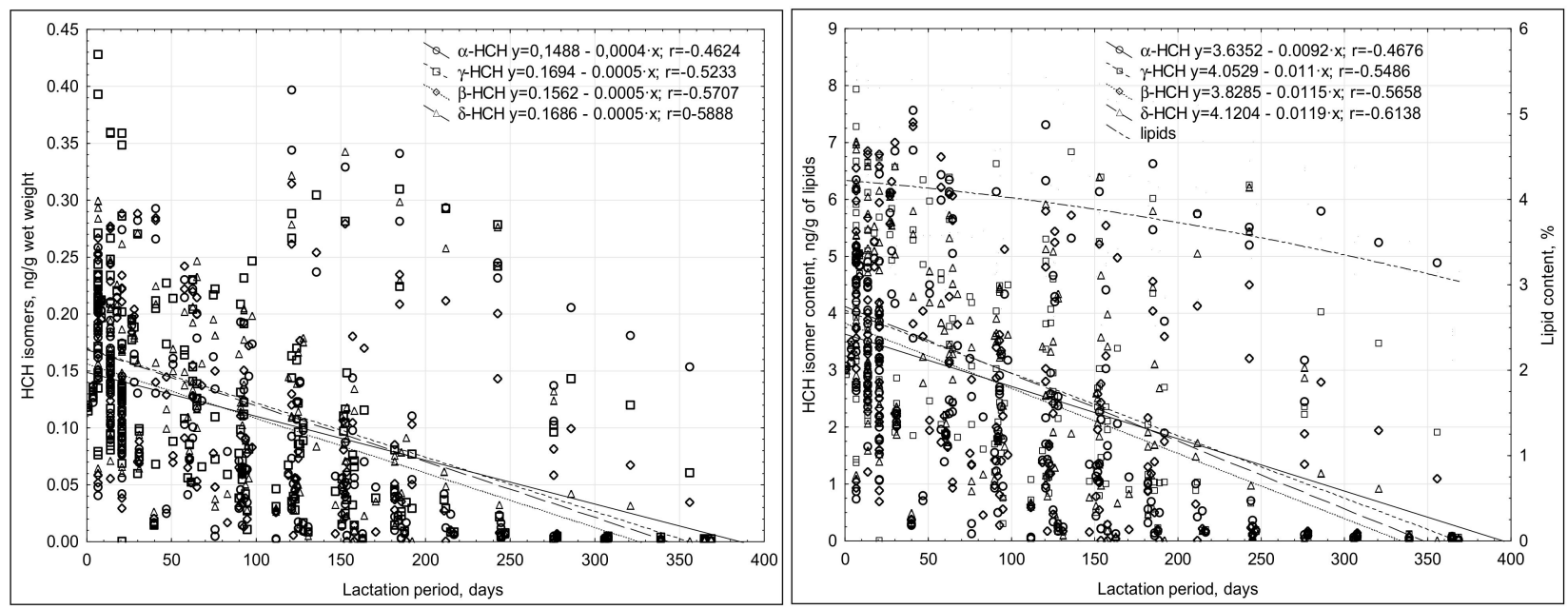

Figure 1. Correlations between the duration of lactation and the concentrations of $\mathrm{HCH}$ isomers in the breast milk. 
Table 4. Mean content of selected organochlorine pesticides in breast milk.

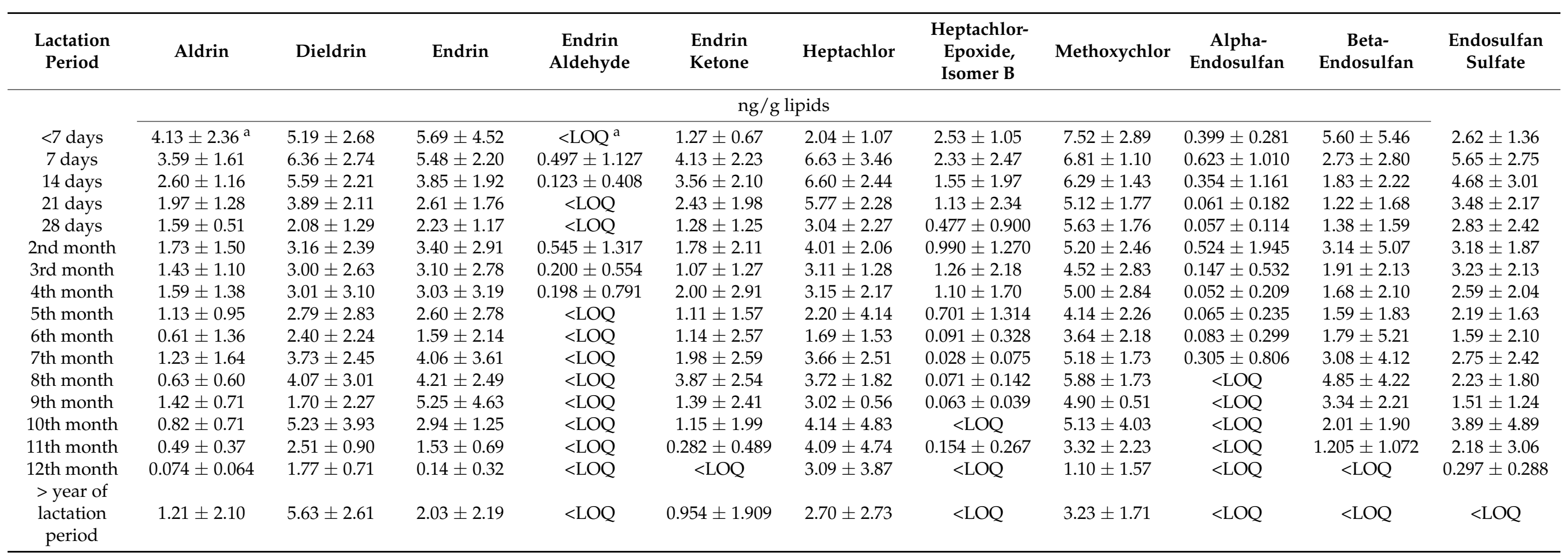


Table 5. Mean content of selected organochlorine pesticides in breast milk—continued.

\begin{tabular}{|c|c|c|c|c|c|c|c|}
\hline $\begin{array}{l}\text { Lactation } \\
\text { Period }\end{array}$ & $\alpha-\mathrm{HCH}$ & $\gamma-\mathbf{H C H}$ & $\beta-\mathrm{HCH}$ & $\delta-\mathrm{HCH}$ & $p, p^{\prime}-\mathrm{DDE}$ & $p, p^{\prime}$-DDD & $p, p^{\prime}-\mathrm{DDT}$ \\
\hline & \multicolumn{7}{|c|}{ ng/g lipids } \\
\hline$<7$ days & $3.15 \pm 0.12^{\mathrm{a}}$ & $3.13 \pm 0.30$ & $3.19 \pm 0.26$ & $3.18 \pm 0.26$ & $0.115 \pm 0.013$ & $0.118 \pm 0.020$ & $0.132 \pm 0.057$ \\
\hline 7 days & $4.05 \pm 1.45$ & $4.53 \pm 1.72$ & $4.36 \pm 1.53$ & $4.68 \pm 1.80$ & $0.221 \pm 0.065$ & $0.245 \pm 0.080$ & $0.239 \pm 0.072$ \\
\hline 14 days & $3.71 \pm 0.962$ & $4.01 \pm 1.65$ & $3.80 \pm 1.53$ & $4.37 \pm 1.49$ & $0.186 \pm 0.056$ & $0.208 \pm 0.066$ & $0.203 \pm 0.057$ \\
\hline 21 days & $3.25 \pm 1.06$ & $3.43 \pm 2.17$ & $3.24 \pm 1.95$ & $3.57 \pm 1.50$ & $0.161 \pm 0.044$ & $0.189 \pm 0.052$ & $0.185 \pm 0.042$ \\
\hline 28 days & $3.71 \pm 1.93$ & $4.01 \pm 1.79$ & $4.08 \pm 2.23$ & $3.92 \pm 2.06$ & $0.140 \pm 0.027$ & $0.147 \pm 0.022$ & $0.159 \pm 0.011$ \\
\hline 2nd month & $2.88 \pm 2.06$ & $3.30 \pm 1.80$ & $2.88 \pm 2.06$ & $3.63 \pm 1.57$ & $0.138 \pm 0.054$ & $0.162 \pm 0.059$ & $0.159 \pm 0.057$ \\
\hline 3rd month & $2.54 \pm 1.10$ & $2.95 \pm 1.51$ & $2.41 \pm 1.88$ & $3.14 \pm 1.44$ & $0.111 \pm 0.051$ & $0.126 \pm 0.055$ & $0.127 \pm 0.054$ \\
\hline 4th month & $2.54 \pm 2.19$ & $2.70 \pm 2.08$ & $2.15 \pm 1.99$ & $2.50 \pm 1.53$ & $0.111 \pm 0.075$ & $0.125 \pm 0.079$ & $0.121 \pm 0.076$ \\
\hline 5th month & $2.00 \pm 1.86$ & $2.22 \pm 1.53$ & $1.94 \pm 1.91$ & $2.13 \pm 1.74$ & $0.085 \pm 0.069$ & $0.094 \pm 0.064$ & $0.101 \pm 0.071$ \\
\hline 6th month & $1.56 \pm 1.16$ & $1.75 \pm 1.92$ & $1.42 \pm 1.07$ & $1.37 \pm 1.31$ & $0.066 \pm 0.060$ & $0.072 \pm 0.049$ & $0.074 \pm 0.051$ \\
\hline 7th month & $1.67 \pm 1.19$ & $1.39 \pm 1.99$ & $1.37 \pm 1.09$ & $1.24 \pm 1.82$ & $0.088 \pm 0.072$ & $0.088 \pm 0.050$ & $0.082 \pm 0.055$ \\
\hline 8th month & $1.63 \pm 2.49$ & $1.70 \pm 1.78$ & $1.09 \pm 1.84$ & $1.76 \pm 1.74$ & $0.097 \pm 0.057$ & $0.086 \pm 0.048$ & $0.082 \pm 0.049$ \\
\hline 9th month & $1.00 \pm 1.56$ & $0.814 \pm 1.28$ & $0.61 \pm 0.87$ & $1.04 \pm 1.66$ & $0.082 \pm 0.026$ & $0.068 \pm 0.016$ & $0.071 \pm 0.044$ \\
\hline 10th month & $1.98 \pm 3.31$ & $1.39 \pm 2.28$ & $0.98 \pm 1.56$ & $0.44 \pm 0.64$ & $0.094 \pm 0.042$ & $0.062 \pm 0.021$ & $0.076 \pm 0.037$ \\
\hline 11th month & $1.78 \pm 2.96$ & $1.20 \pm 1.97$ & $0.65 \pm 1.11$ & $0.34 \pm 0.50$ & $0.067 \pm 0.023$ & $0.039 \pm 0.013$ & $0.050 \pm 0.025$ \\
\hline $\begin{array}{l}\text { 12th month } \\
>\text { vear of }\end{array}$ & $1.65 \pm 1.80$ & $0.661 \pm 1.08$ & $0.37 \pm 0.33$ & $0.017 \pm 0.023$ & $0.036 \pm 0.011$ & $0.016 \pm 0.008$ & $0.019 \pm 0.012$ \\
\hline $\begin{array}{l}\text { lactation } \\
\text { period }\end{array}$ & $0.054 \pm 0.009$ & $0.070 \pm 0.015$ & $0.031 \pm 0.008$ & $0.049 \pm 0.013$ & $0.009 \pm 0.001$ & $0.010 \pm 0.001$ & $0.009 \pm 0.002$ \\
\hline
\end{tabular}

${ }^{a}$ Arithmetic average \pm standard deviation.
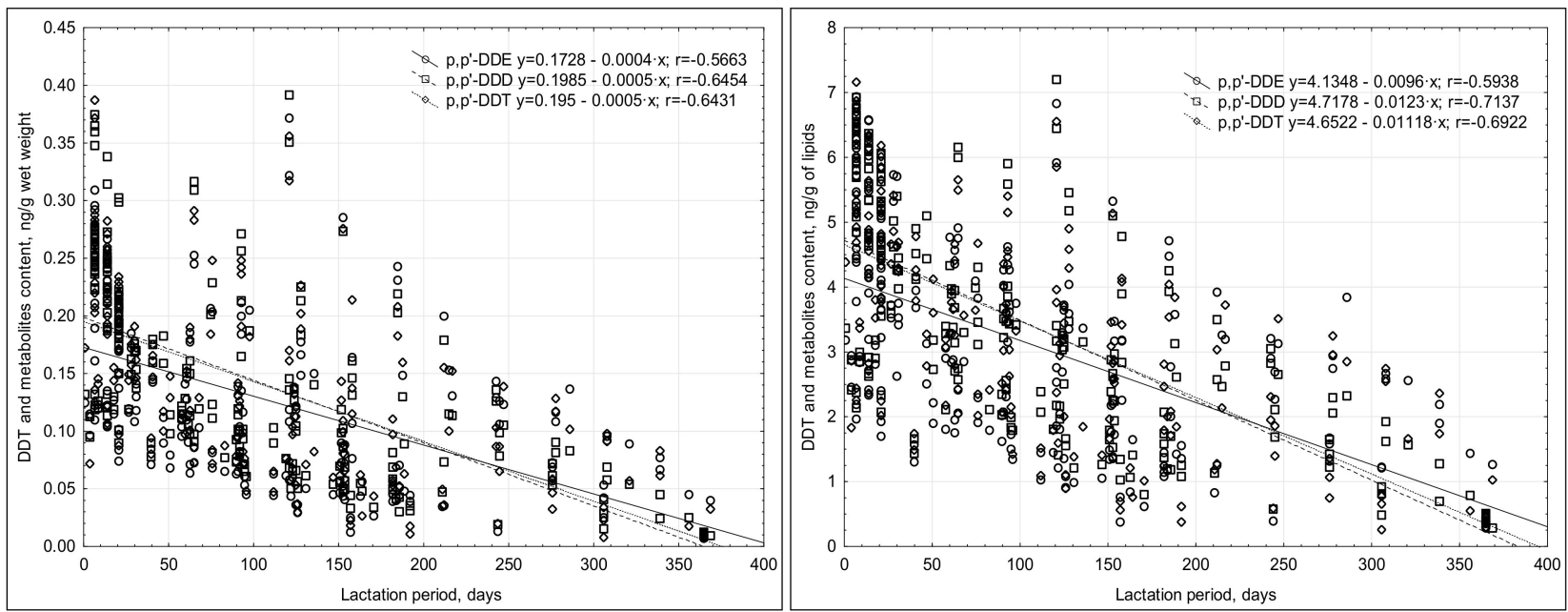

Figure 2. Correlations between the duration of lactation and the concentrations of DDT metabolites in the breast milk.

The concentrations of beta-endosulfan and endosulfan sulphate differed significantly in most cases in certain periods of lactation. Weak or moderately-positive correlations of protein content with alpha-endosulfan $(r=0.234)$ and beta-endosulfan $(r=0.330)$ were observed.

Among the $\mathrm{HCH}$ metabolites, $\delta-\mathrm{HCH}$ and $\gamma-\mathrm{HCH}$ dominated (Table 5), and the maximum contents of $\gamma-\mathrm{HCH}$ and $\delta-\mathrm{HCH}$ were noted after seven days of lactation.

The correlation coefficient between the concentrations of $\mathrm{HCH}$ isomers and lipid content ranged from 0.30 to 0.48 (Figure 3). The lack of strong correlations indicated that changes in milk fat content were not the only reason for the changes in the concentration of the compounds in the milk's wet weight. 

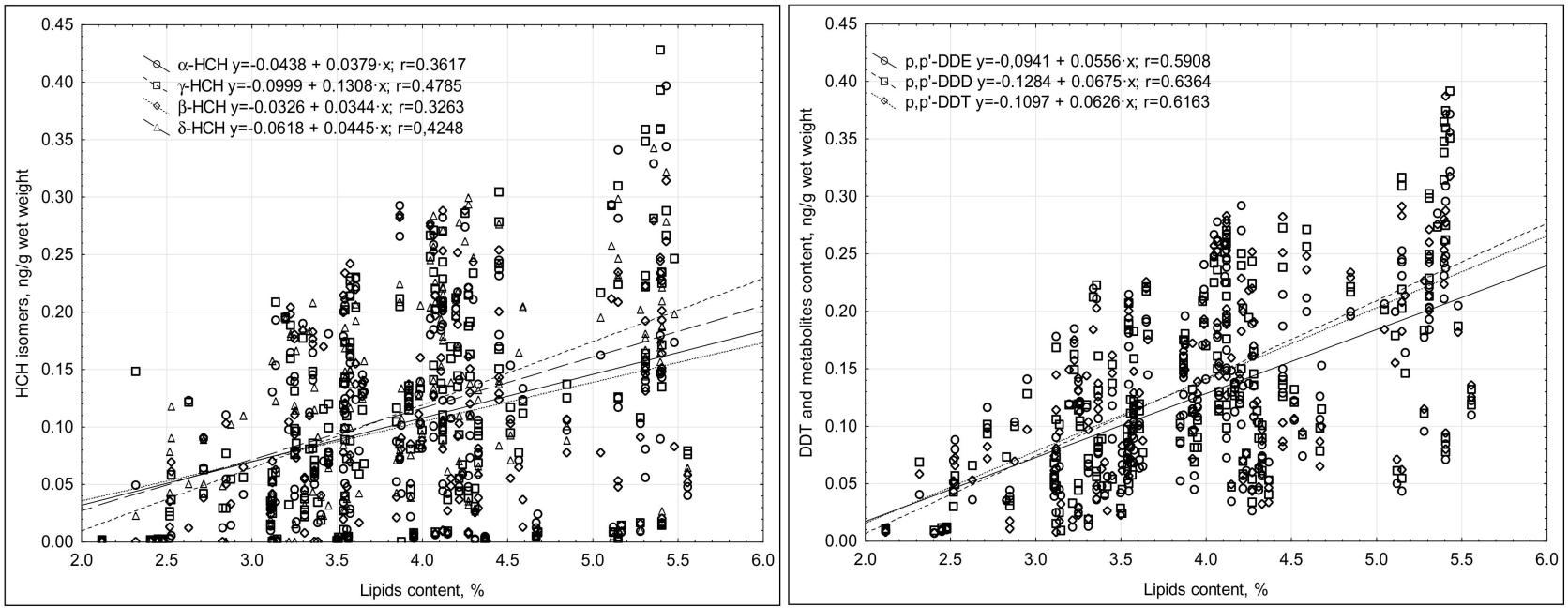

Figure 3. Correlations between the content of $\mathrm{HCH}$ isomers and DDT metabolites and the lipid content of the breast milk tested.

A significant decrease in DDT metabolite concentrations was noted in the milk during lactation $(r=-0.645-0.566)$ (Table 5), and of the DDT metabolites, $\mathrm{p}, \mathrm{p}^{\prime}$-DDD dominated.

The changes in the content of DDT compounds in the milk's wet weight depended, to a large extent, on the changes in the lipid content, as was evidenced by the correlation coefficient $r$ being within a range of $0.591\left(\mathrm{p}, \mathrm{p}^{\prime}\right.$-DDE) and 0.636 ( $\mathrm{p}, \mathrm{p}^{\prime}$-DDD) (Figure 3).

Additionally, the RDA analysis did not show that maternal age, maternal body weight before pregnancy, or the number of births had a significant effect on the concentration of the compounds analyzed in the breast milk.

\subsection{Estimating the Infant Health Risk Associated with Breastfeeding}

The calculations concerning the volume of ingested milk were based on the literature [23-25]. In the assessment of infant health risk, no significant differences were found between the parameters specified for female and male infants. The data from the literature indicate that male infants consume an average of $76 \mathrm{~mL}$ more food than female infants. The amount of milk consumed daily by one infant ranges from $478 \mathrm{~mL}$ to $1.356 \mathrm{~mL}$, with an average of $798 \mathrm{~mL}$. The LADD ranged from $3.30 \times 10^{-5}$ to $7.84 \times 10^{-4} \mathrm{mg} / \mathrm{kg}$ bw $/$ day. The highest LADD value was recorded for both female and male infants in the first week of lactation, after which it gradually decreased with the length of the feeding period (Figure 4).

The HQ values were also significantly below 1 and ranged from $1.40 \times 10^{-6}$ to $1.21 \times 10^{-5}$ (Figure 4) [34].

The values of the indicators above signaled that the residues of organochlorine pesticides detected in breast milk posed a low risk to infants, and that the highest uptake of these toxic substances was at the beginning of the breastfeeding period. 

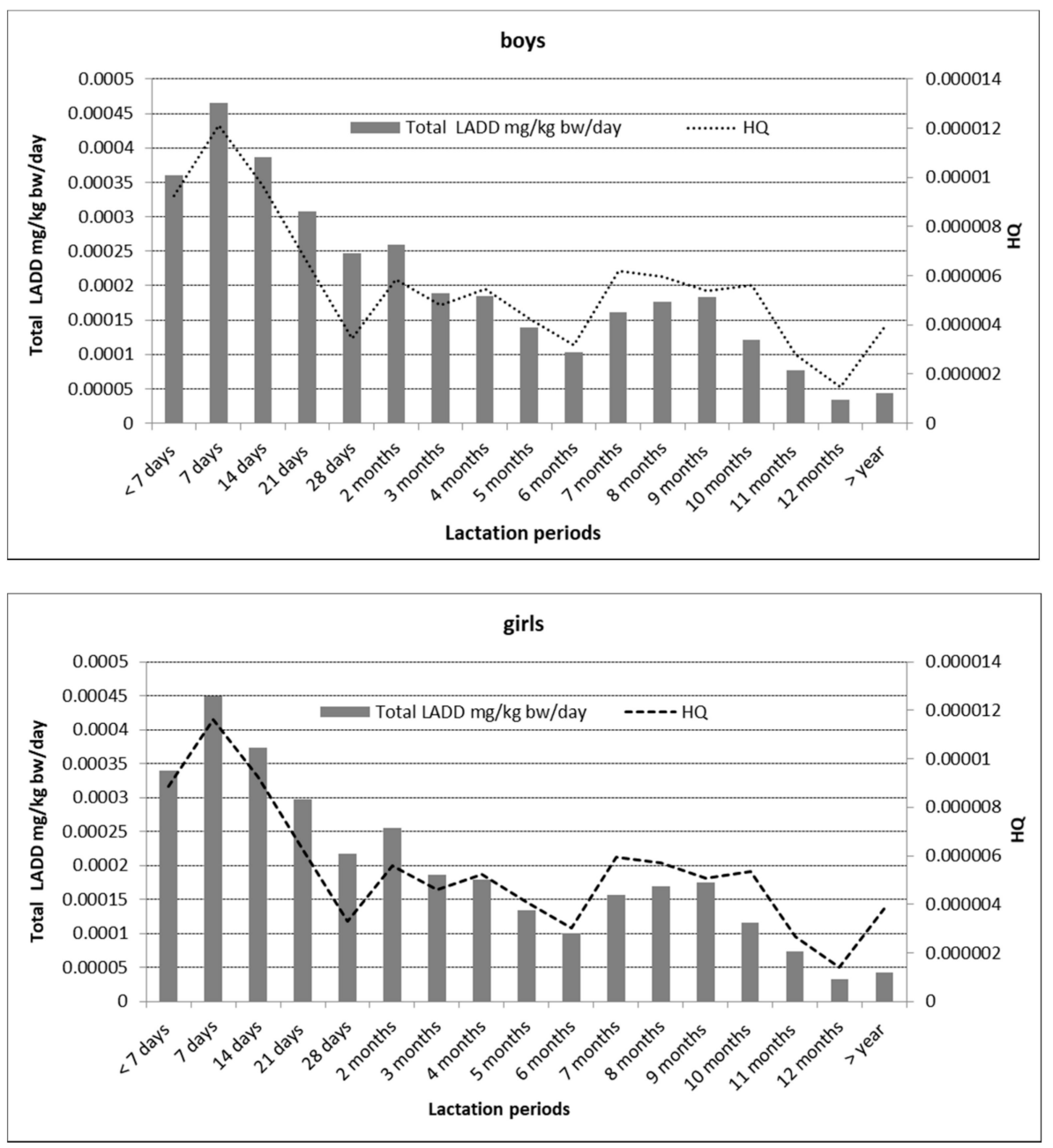

Figure 4. Assessment of infant exposure by sex.

\subsection{Redundancy Analysis (RDA)}

The ordination analyses indicated that there were multidimensional relationships among the explanatory and dependent variables. In each case, CCA analysis reduced the number of independent variables, while the DCA analysis resulted in a gradient of the first DCA axis below two standard deviations. Therefore, the RDA method was chosen.

The multidimensional relationships were analyzed between the explanatory variables (lactation period; place of residence; education; maternal age; maternal body weight prior to pregnancy; infant weight; dry milk weight; milk lactose, protein, and lipid content; and maternal habits, such as smoking and fruit, beef, pork, rice, egg, and dairy product consumption) and dependent variables (i.e., concentrations of compounds).

The first RDA axis explained $40.9 \%$ of the total variance, while RDA2 explained $7.9 \%$ of the endosulfan compounds (Figure 5A). Both axes were statistically significant (ANOVA test; $p<0.05$ ). The dry mass, fat, protein, and lactose levels made the highest positive contributions to RDA1, while RDA2 was mainly linked to the duration of lactation and the place of residence. 

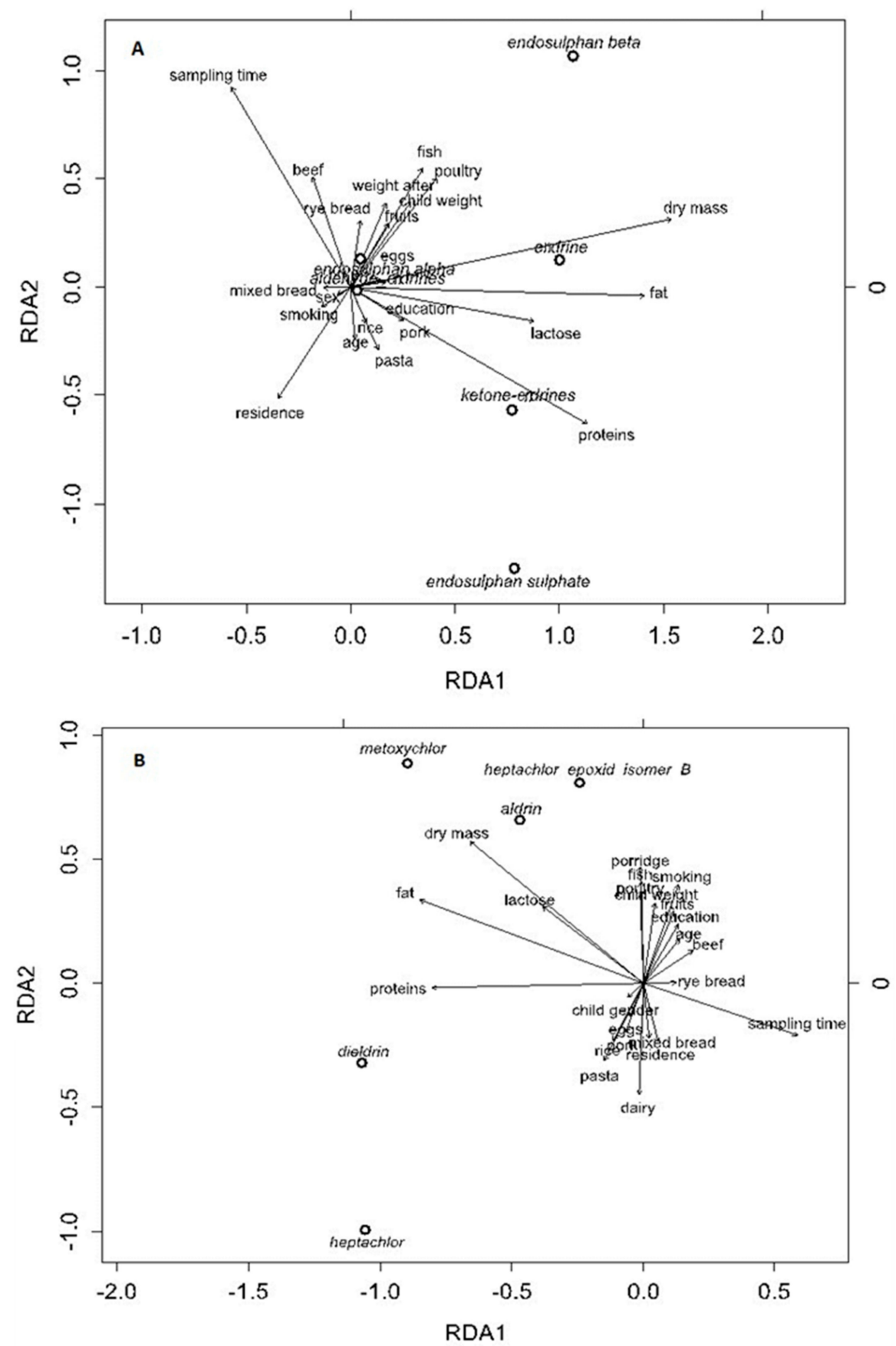

Figure 5. Cont. 


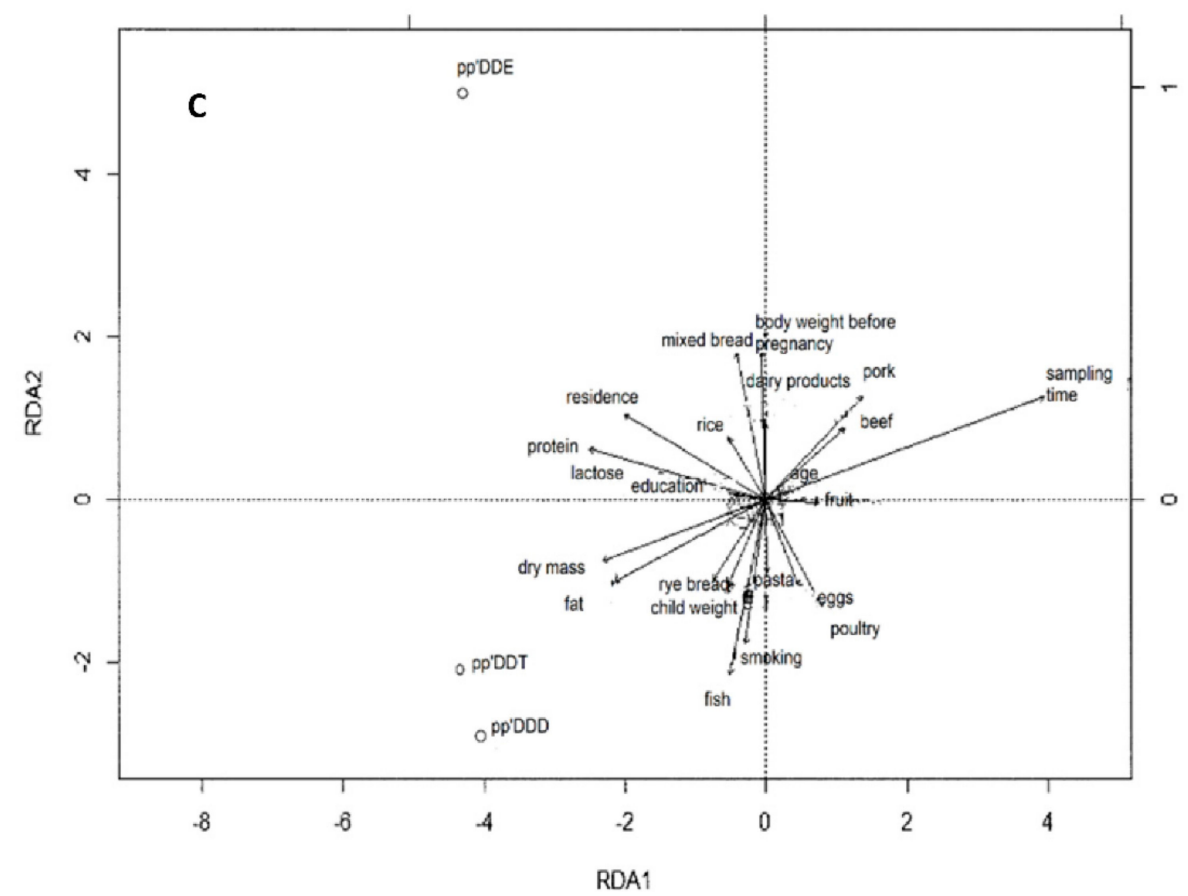

Figure 5. RDA biplot for the relationships between the OCP compounds ((A)-endosulfan compounds, endrin compounds, (B)-methoxychlor, heptachlor, heptachlor epoxide, aldrin, dieldrin, (C)-pp'DDT, $\mathrm{pp}$ 'DDE, $\mathrm{pp}$ 'DDD) and the explanatory variables.

Beta-endosulfan levels were mostly positively correlated with fish and poultry consumption, while the total endosulfan sulphate concentrations decreased over the lactation period. The endrin ketone concentrations increased with protein content, and endrin concentrations correlated positively with dry matter content (Figure 5A).

In Figure $5 \mathrm{~B}$, the first RDA axis explained $70.8 \%$ of the total variance, while RDA2 explained $14.5 \%$. Both axes were statistically significant (ANOVA test; $p<0.05$ ). The results of the RDA analysis (Figure 5B) also indicated that the protein and fat concentrations and milk collection time made the highest positive contribution to RDA1, while RDA2 was mainly linked to the breast milk dry matter content; maternal consumption of dairy, fish and poultry; and maternal smoking. The methoxychlor and aldrin levels were mostly positively correlated with breast milk dry matter and lactose concentrations, but they decreased over the lactation period (Figure 5B).

The RDA analysis did not show any relevant influence of the number of births on the concentrations of the pesticides studied in breast milk. Moreover, no substantial correlation in the levels of toxins determined was found between the milk samples collected from primiparous and multiparous mothers.

Regarding the dependence on milk fat, the first axis RDA1 explained $95.1 \%$ of the total variance, while RDA2 explained $2.7 \%$ (Figure $5 \mathrm{C}$ ). Both axes were statistically significant (ANOVA test; $p<0.05$ ).

The largest share in the RDA1 axis were factors such as milk intake time, protein, dry matter, and milk fat content. In contrast, the RDA2 axis was predominantly linked to the number of cigarettes that the mothers smoked; the volume of maternal fish, poultry and mixed bread consumption; and maternal body weight before pregnancy (Figure 5C). Both $\mathrm{p}, \mathrm{p}^{\prime}$-DDT and $\mathrm{p}, \mathrm{p}^{\prime}$-DDD were strongly positively correlated with milk fat and dry matter content, but the content of these compounds decreased significantly over the time of milk intake. The RDA analysis also showed negative correlations between $\mathrm{p}, \mathrm{p}^{\prime}$-DDT and $\mathrm{p}, \mathrm{p}^{\prime}$-DDD concentrations and maternal pork and beef consumption. The content of $\mathrm{p}, \mathrm{p}^{\prime}$-DDE in the milk showed a positive correlation with the frequency at which the mothers consumed dairy products and mixed bread, and a negative correlation with their 
poultry and egg consumption (Figure 5C). However, no significant $(p<0.05)$ correlations were found for $\mathrm{HCH}$ isomers. The number of births, maternal weight, and age did not affect the content of $\mathrm{HCH}$ isomers in the milk sampled during lactation.

\section{Discussion}

Human milk provides vital protection for and contributes to the development of babies by providing all of the essential nutritional components, such as macronutrients, vitamins, minerals, long-chain polyunsaturated fatty acids, and cytokines. Human milk is recommended as the sole source of nutrition for all babies during the first six months of life. Unfortunately, despite these benefits, human milk also tends to accumulate lipophilic toxins, especially persistent organochlorine pesticides. Their ubiquitous distribution in various environments has a direct effect on human endocrine and reproductive systems. OCPs can reduce fertility and interfere with hormone secretion or activity.

In the light of the health risk to infants, it is important to test for the presence of organochlorine pesticides in breast milk, and to look for the correlation between the presence of these compounds and the age of the mothers, body weight, number of births, duration of lactation, and nutritional habits associated with natural feeding.

The residues of the pesticides (OCPs) analyzed in human milk were at different levels. The literature data show a wide range of pesticide residues in breast milk, depending on the country.

Overall, the ED pesticides in human milk have decreased over the past 30 years in many countries. For example, for DDT, there has been a decrease from 2000-32,000 ng/g lipids to $0.1 \mathrm{ng} / \mathrm{g}$ lipids since the 1990s. [35,36]. Based on the results obtained in this study, it can be concluded that there is a similar tendency in Poland [37].

For example, other studies reported the content of aldrin ranging between 0.009 and $40 \mathrm{ng} / \mathrm{g}$ lipids, and dieldrin ranging between 1 and $713 \mathrm{ng} / \mathrm{g}$ lipids [11-13,16,38]. In light of these data, the values obtained in the current study were low. Higher dieldrin concentrations in breast milk were also reported by many authors in different countries, such as Australia and New Zealand [12,39]. The high dieldrin levels in breast milk collected from mothers in different countries could have resulted from its persistence in the natural environment and its ability to bioaccumulate.

In contrast to the present study, Croes et al. [16] did not report either heptachlor or heptachlor epoxide isomer B in breast milk collected from rural Belgian mothers. Mueller et al. [39] found heptachlor-epoxide isomer B in breast milk collected between the second and eighth weeks of lactation in samples from rural and urban Australia, and the levels of this averaged $16.7 \mathrm{ng} / \mathrm{g}$ lipids in the samples from rural areas, while the average in samples from urban areas was $2.21 \mathrm{ng} / \mathrm{g}$ lipids. These values were significantly higher compared to the results obtained in our study. Lower concentrations of heptachlor $(0.013 \mathrm{ng} / \mathrm{g}$ lipid $)$ and heptachlor epoxide isomer B $(0.456 \mathrm{ng} / \mathrm{g}$ lipid) were reported in the breast milk samples collected from women residing in New Zealand [12].

Studies conducted from 2007 to 2008 in Turkey by Çok et al. [13] confirmed the presence of alpha-endosulfan and beta-endosulfan in breast milk at levels that were considerably higher compared to those found in the present study. These authors observed similar levels of alpha-endosulfan in both primiparous and multiparous mothers, and they reported beta-endosulfan residue averages of $38 \mathrm{ng} / \mathrm{g}$ lipids. Similar findings have been reported by many authors $[12,14]$.

Not until 2010 were $\alpha-\mathrm{HCH}, \beta-\mathrm{HCH}$, and lindane included among the substances regulated by the Stockholm Convention, which resulted in a total ban on their production and use. The contents of this pesticide in human milk were recorded in 2000-2004 in Norway (14 ng/g lipids) and Sweden (10 ng/g lipids) [40,41].

The presence of $\mathrm{HCH}$ in human milk can result from the incorrect use of pesticide preparations, and from noncompliance with waiting periods in the years before their use was banned. A secondary effect of the occurrence of these compounds in the environment is their accumulation in the raw materials used in foods that are consumed by future 
mothers. Bulut et al. [42], Fromberg et al. [43], Witczak [18], and Witczak and Pohoryło [44] all reached this conclusion in their studies on the presence of total $\mathrm{HCH}$ in cow's milk, sheep's milk, butter, and cheese. Of all isomers, $\beta-\mathrm{HCH}$ was noted most commonly, which is a result of its high stability and persistence. In the human body, the $\beta$-isomer is usually present in higher concentrations than those of $\alpha$ - and $\gamma-\mathrm{HCH}$, which metabolize into $\beta-\mathrm{HCH}$ [45]. The $\beta-\mathrm{HCH}$ content in the present study (average $2.03 \mathrm{ng} / \mathrm{g}$ lipids) corresponds to the results of Croes et al. [16] and Klinčić et al. [46] in Belgium and Croatia, respectively. Both teams of researchers found the content of this isomer to be in the range of $0.6-9.0 \mathrm{ng} / \mathrm{g}$ lipids. The dominance of $\beta-\mathrm{HCH}$ in human milk can be affected by a number of mechanisms that modify the chemical structure of these compounds. For example, in the environment, some bacteria can slowly isomerize lindane into $\alpha-, \beta$ - and $\delta-\mathrm{HCH}$, mainly under anaerobic conditions. $\mathrm{HCH}$ degradation is slow, and the efficiency of these processes under anaerobic conditions is greater than in aerobic conditions. The high content of these compounds can result from their presence in the environment, as a result of the long-term use of $\mathrm{HCH}$ to fight malaria or typhoid, and because they are highly stable and resistant to degradation $[8,47]$. The highest $\mathrm{HCH}$ value reported was in the milk of women in India in 2000-2012 (35,000 ng/g lipids) [48]. Such a high level of this pesticide could be because India was one of the leading producers and consumers of chlorinated pesticides, particularly of $\mathrm{HCH}$, until the ban/restriction of their use in the late 1990s. However, a significant proportion of these compounds are still permitted for use in malaria control.

A large discrepancy can be noted when our results are compared with the data available in the literature. Polder et al. [49] demonstrated that milk consumed by infants is completely safe; however, Müller et al. [38] reached different conclusions. These authors reported that the tolerated daily intake of total DDT was exceeded in human milk samples from Northern Tanzania. Gebremichael et al. [50] reported that Ethiopia had one of the largest stocks of obsolete pesticides in Africa. Exposure to high concentrations of DDT compounds can have many negative health consequences. In Poland, the content in breast milk of DDT metabolites has decreased over the years [37]. In the light of the preceding data, the average total DDT content determined in the current study was low $(8.14 \mathrm{ng} / \mathrm{g}$ lipids). The significant reductions in the total DDT content could have resulted from the restrictive provisions of the total ban on the use of plant protection products not only in the Stockholm Convention [15] but also from those imposed in all European Union countries. As in the case of $\mathrm{HCH}$ isomers, studies have shown that expectant mothers' consumption of cow's milk and milk products might be one of the ways in which they are exposed to DDT [18]. The main source of organochlorine compounds for dairy animals is contaminated feed [51]; the degree that DDT metabolites transfer into milk ranges from $4 \%$ $\left(\mathrm{p}, \mathrm{p}^{\prime}\right.$-DDT) to $80 \%\left(\mathrm{p}, \mathrm{p}^{\prime}\right.$-DDE) [52].

In this study, the concentration of selected organochlorine pesticides in the mother's milk may have been associated with the individual features of the mother and her infant, as well as their dietary habits.

In our research, the RDA analysis did not show that maternal age, maternal body weight before pregnancy, or the number of births had a significant effect on the concentration of the compounds analyzed in the breast milk.

In relation to maternal age, similar results were obtained by Hassine et al. [8] for $\mathrm{HCH}$ isomers, and by Behrooz et al. [53] and Azeredo et al. [54] for DDT and its metabolites. The lack of correlation between the content of organochlorine pesticides and the age of the mothers may result from too-short an exposure period, or the disappearance of these compounds in the environment. However, some authors have noted various correlations between the concentration of these pesticides in milk and the age of the mothers, positive $[55,56]$ or negative [46]. The increase in the concentration of organochlorine pesticides with the age of mothers may also be the result of women's eating habits. It has been proven that pesticides are resistant to metabolic processes in the body, and that they bioaccumulate with age [57,58]. The studies by Dimitriadou et al. [56] and Müller et al. [38] brought similar conclusions to ours: the body weight of the women, both before and after pregnancy, influ- 
enced the changes in the concentration of these compounds in the milk. The redundancy analysis carried out in this study confirmed that the content of organochlorine pesticides in human milk was not influenced by the sex of the child, which was also confirmed in $[38,56]$. An interesting relationship was also observed by Croes et al. [16]. The authors proved that the level of $\sum D D T$ in human milk increased with the increase in the consumption of dairy products by future mothers. Our research, however, did not confirm a similar relationship.

This assessment of infant exposure to the residues of selected OCPs in human milk is the first study of its kind in northwestern Poland.

The risk associated with the exposure to OCPs depends on the dose, the duration of exposure, and whether or not the acceptable daily intake (ADI) is exceeded. This is important because infants consume many times more food per kilogram of body weight than do adults; they are in a phase of dynamic growth and development, and their exposure to the toxic effects of EDCs is much higher.

The conducted risk analysis allowed for the evaluation of the tested food as safe for infants. It has also been shown that, with the increasing period of lactation, the content of organochlorine pesticides in milk decreases, with the largest pool of DDT and $\mathrm{HCH}$ being accumulated in the milk by the infant in the first weeks of life. This is a valuable observation which is also important from a clinical point of view. Attention was also paid to the potential possibility of lowering the content of organochlorine compounds in breast milk by following specific nutritional recommendations for women expecting a child, e.g., avoiding the excessive consumption of fish, especially of unknown origin, and eliminating smoking. The diet of pregnant women may significantly affect the concentration of OCPs in human milk, because they take up these compounds mainly from food. The highest residues of these compounds was found in fish, meat, poultry, eggs, milk, and dairy products, as well as in vegetable oils, nuts, avocado, sesame, or olives [59-61]. This is due to the lipophilicity, persistence, and tendency to cumulation of these compounds, both in plant and animal organisms.

\section{Conclusions}

In the breast milk, a decrease in the content of the analysed OCPs, as well as the dry matter, lipids, and protein over the lactation periods analysed were observed. Moreover, our research showed that the highest $\mathrm{OCP}$ concentrations in breast milk occurred primarily within the first month of lactation.

The RDA analysis indicated that the type of diet that pregnant women consume has an important impact on the pesticide residue levels in their breast milk. Among others, the concentration of beta-endosulfan residues in breast milk correlated positively with the frequency of fish and poultry consumption by pregnant women. It was found that the maternal consumption of certain food products, in particular pork, beef, poultry, eggs, and dairy products, could have affected the content of DDT and its metabolites in the breast milk. The levels of beta-endosulfan were primarily positively correlated with maternal fish and poultry consumption. Maternal age, place of residence, and infant birth weight were not correlated with the DDT or HCH concentrations in breast milk.

Current Polish law does not specify the maximum acceptable limits of OCPs in breast milk; therefore, any assessment of breast milk safety regarding OCPs must be made in reference to the regulations on food for infants and young children. The levels of OCP residues in the breast milk examined in this study were below the maximum residue levels (MRL) (set forth in Polish Journal of Laws no. 180 item 1214 of 16 September 2010 [62] and Polish Journal of Laws item 1026 of 16 June 2015 [63].

The analysis of the organochlorine pesticide residues in breast milk indicated that the values of the parameters used to assess the infant risk were very low. The assessment of infant health risk indicated that there were no significant differences for female or male infants between parameters such as LADD and HQ. A gradual decrease was observed in LADD over longer breastfeeding periods. The HQ values were also low, at less than 1 . The analysis of the results of this study led to the conclusion that mothers' milk, although it is 
not devoid of pesticide residues, is safe for infants. Despite the presence of organochlorine impurities in breast milk, the risk assessment parameters proved that breast milk is safe for infant health. However, we would like to emphasize the need for the continuous monitoring of endocrine-disrupting organochlorine xenobiotics in human milk. This is particularly important because of the lack of legal regulations on this matter. There is also a potential possibility of lowering the content of organochlorine compounds in breast milk by adhering to certain nutritional recommendations for pregnant women, e.g., avoiding the excessive consumption of fish and other raw food materials of unknown origin.

Author Contributions: Conceptualization, A.W.; Methodology, A.W.; Validation, A.W., A.P.; Investigation, A.P. and A.W.; Original Draft Preparation, A.P., A.W. and H.A.-G.; Final editing and preparation of the text, A.W. All authors have read and agreed to the published version of the manuscript.

Funding: This research received no external funding.

Institutional Review Board Statement: The study was conducted according to the guidelines of the Declaration of Helsinki, and approved by The Bioethics Commission at the District Chamber of Physicians in Szczecin consented to the study being conducted (consent of Bioethics Commission No OIL-Sz/MF/KB/452/02/04/2015 of 23 April 2015).

Informed Consent Statement: Informed consent was obtained from all subjects involved in the study.

Data Availability Statement: The data presented in this study are available on request from the corresponding author.

Acknowledgments: The authors are grateful to Mikołaj Protasowicki, the head of the Toxicology Department, for his kindness and support, and to Eng. Agnieszka Strzelczak for help with the statistical analysis.

Conflicts of Interest: The authors declare no conflict of interests.

\section{References}

1. Goldman, A.S. Evolution of immune functions of the mammary gland and protection of the infant. Breastfeed Med. 2012, 7, 132-142. [CrossRef] [PubMed]

2. Routti, H.; Arukwe, A.; Jenssen, B.M.; Letcher, R.J.; Nyman, M.; Bäckman, C. Comparative endocrine disruptive effects of contaminants in ringed seals (Phocahispida) from Svalbard and the Baltic Sea. Comp. Biochem. Physiol. C Toxicol. Pharm. 2010, 152, 306-332. [CrossRef] [PubMed]

3. Mnif, W.; Hassine, A.I.H.; Bouaziz, A. Effect of endocrine disruptor pesticides: A review. Int. J. Environ. Res. Public Health 2011, 8, 2265-2303. [CrossRef] [PubMed]

4. Juberg, D.R. An evaluation of endocrine modulators: Implications for human health. Ecotoxicol. Environ. Saf. 2000, 45, 93-105. [CrossRef] [PubMed]

5. Han, X.; Zhang, F.; Meng, L.; Xu, Y.; Li, Y.; Li, A.; Turyk, M.E.; Yang, R.; Wang, P.; Zhang, J.; et al. Exposure to organochlorine pesticides and the risk of type 2 diabetes in the population of East China. Ecotoxicol. Environ. Saf. 2020, 190, 110125. [CrossRef] [PubMed]

6. Falcon, M.; Olive, J.; Osuna, E.; Barba, A.; Luna, A. HCH and DDT residues in human placentas in Murcia (Spain). Toxicology 2004, 195, 203-208. [CrossRef] [PubMed]

7. Song, S.; Ma, J.; Tian, Q.; Tong, L.; Guo, X. Hexachlorobenzene in human milk collected from Beijing, China. Chemosphere 2013, 91, 145-149. [CrossRef] [PubMed]

8. Hassine, S.B.; Ameur, W.B.; Gandoura, N.; Driss, M.R. Determination of chlorinated pesticides, polychlorinated biphenyls, and polybrominated diphenyl ethers in human milk from Bizerte (Tunisia) in 2010. Chemosphere 2012, 89, 369-377. [CrossRef]

9. Chao, H.R.; Wang, S.L.; Lee, C.C.; Yu, H.Y.; Lu, Y.K.; Papke, O. Level of polychlorinated dibenzo-p-dioxins, dibenzofurans and biphenyls (PCDD/Fs, PCBs) in human milk and the input to infant body burden. Food. Chem. Toxicol. 2004, 42, 1299-1308. [CrossRef]

10. Barr, D.B.; Wang, R.Y.; Needham, L.L. Biologic monitoring of exposure to environmental chemicals throughout the life stages: Requirements and issues for consideration for the national children's study. Environ. Health Perspect. 2005, 113, $1083-1091$. [CrossRef]

11. Rodríguez, Á.G.P.; López, M.I.R.; DelValls Casillas, T.A.; León, J.A.A.; Prusty, B.A.K.; Cervera, F.J. Levels of persistent organic pollutants in breast milk of Maya women in Yucatan, Mexico. Environ. Monit. Assess. 2017, 189, 59. [CrossRef] [PubMed] 
12. Mannetje, A.; Coakley, J.; Bridgen, P.; Brooks, C.; Harrad, S.; Smith, A.H.; Pearce, N.; Douwes, J. Current concentrations, temporal trends and determinants of persistent organic pollutants in breast milk of New Zealand women. Sci. Total Environ. 2013, 458-460, 399-407. [CrossRef] [PubMed]

13. Çok, İ; Mazmanci, B.; Mazmanci, M.A.; Turgut, C.; Henkelmann, B.; Schramm, K.W. Analysis of human milk to assess exposure to PAHs, PCBs and organochlorine pesticides in the vicinity Mediterranean city Mersin, Turkey. Environ. Int. 2012, 40, 63-69. [CrossRef] [PubMed]

14. Bedi, J.S.; Gill, J.P.S.; Aulakh, R.S.; Kaur, P.; Sharma, A.; Pooni, P.A. Pesticide residues in human breast milk: Risk assessment for infants from Punjab, India. Sci. Total Environ. 2013, 463-464, 720-726. [CrossRef] [PubMed]

15. Stockholm Convention. Available online: http://www.pops.int/TheConvention/Overview/TextoftheConvention/tabid/2232 /Default.aspx (accessed on 14 January 2017).

16. Croes, K.; Colles, A.; Koppen, G.; Govarts, E.; Bruckers, L.; Van de Mieroop, E.; Nelen, V.; Covaci, A.; Dirtu, A.C.; Thomsen, C.; et al. Persistent organic pollutants (POPs) in human milk: A biomonitoring study in rural areas of Flanders (Belgium). Chemosphere 2012, 89, 988-994. [CrossRef]

17. Malarvannan, G.; Isobe, T.; Covaci, A.; Prudente, M.; Tanabe, S. Accumulation of brominated flame retardants and polychlorinated biphenyls in human breast milk and scalp hair from the Philippines: Levels, distribution and profiles. Sci. Total Environ. 2013, 442, 366-379. [CrossRef]

18. Witczak, A. Studium Obecności Kongenerów PCB w Mleku i Produktach Mleczarskich w Aspekcie Ryzyka Zdrowotnego Oraz Wpływu Procesu Technologicznego Na Poziom Tych Zwiazków [in Polish-Study of PCB Congener Presence in Milk and Dairy Products in Relation to Health Hazards and the Influence of Technological Process on the Levels of These Compounds]; Wydawnictwo Uczelniane Zachodniopomorskiego Uniwersytetu Technologicznego w Szczecinie: Szczecin, Poland, 2013; ISBN 978-83-7663-144-8.

19. EU Commission Directive. 2002/63/EC of 11 July 2002 Establishing Community Methods of Sampling for the Official Control of Pesticide Residues in and on Products of Plant and Animal Origin and Repealing Directive 79/700/EEC. Available online: https:/ / eur-lex.europa.eu/legal-content/EN/TXT/PDF/?uri=CELEX:32002L0063\&from=EN (accessed on 1 August 2020).

20. Buranatrevedh, S. Cancer risk assessment of toxaphene. Ind. Health 2004, 42, 321-327. [CrossRef]

21. Kumar, B.; Mishra, M.; Verma, V.K.; Kumar, S.; Sharma, C.S. Distribution of Dichlorodiphenyltrichloroethane (DDT) and Hexachlorocyclohexane (HCH) in Urban Soils and Risk Assessment. J. Xenobiot. 2013, 3, 1-8. [CrossRef]

22. Witczak, A.; Abdel-Gawad, H. Assessment of Health risk from organochlorine pesticides residues in high-Fat spreadable foods produced in Poland. J. Environ. Sci. Health 2014, 49, 917-928. [CrossRef]

23. Kent, J.C.; Mitoulas, L.R.; Cregan, M.D.; Ramsay, D.T.; Doherty, D.A.; Hartmann, P.E. Volume and frequency of breastfeeds and fat content of breast milk throughout the day. Pediatrics 2006, 117, 387-395. [CrossRef]

24. Kent, J.C.; Hepworth, A.R.; Sherriff, J.L.; Cox, D.B.; Mitoulas, L.R.; Hartmann, P.E. Longitudinal changes in breastfeeding patterns from 1 to 6 months of lactation. Breastfeed Med. 2013, 8, 401-407. [CrossRef] [PubMed]

25. World Health Organization. Child Growth Standards. Available online: www.who.int/childgrowth/standards/en/ (accessed on 14 July 2020).

26. Guilford, J.P. Psychometric Methods, 2nd ed.; McGraw-Hill: New York, NY, USA, 1954.

27. Gauch, H.G. Noise reduction by eigenvector ordinations. Ecology 1982, 63, 1643-1649. [CrossRef]

28. Ter Braak, C.J.F.; Prentice, I.C. A Theory of Gradient Analysis. Adv. Ecol. Res. 1988, 18, 271-317. [CrossRef]

29. Gross, J.J. Individual Differences in Two Emotion Regulation Processes: Implications for Affect, Relationships, and Well-Being. J. Pers. Soc. Psychol. 2003, 85, 348-362. [CrossRef]

30. Legendre, P.; Oksanen, J.; Ter Braak, C.J.F. Testing the significance of canonical axes in redundancy analysis. Methods Ecol. Evol. 2011, 2, 269-277. [CrossRef]

31. Legendre, P.; Legendre, L. Numerical Ecology. In Developments in Environmental Modelling; Elsevier: Amsterdam, The Netherlands, 1998; 853p.

32. Ter Braak, C.J.F. Ordination. In Data Analysis in Community and Landscape Ecology; Jongman, R.H.G., Ter Braak, C.J.F., van Tongeren, O.F.R., Eds.; Cambridge University Press: Cambridge, UK, 1995; pp. 91-173.

33. The R Foundation for Statistical Computing. 2009. Available online: https:/ / cran.r-project.org/ (accessed on 24 May 2019).

34. Available online: https://cfpub.epa.gov/ncea/iris/search/index.cfm?first_letter=M (accessed on 21 January 2020).

35. Çok, İ; Bilgili, A.; Özdemir, M.; Özbek, H.; Bilgili, N.; Burgaz, S. Organochlorine pesticide residues in human breast milk from agricultural regions of Turkey, 1995-1996. Bull. Environ. Contam. Toxicol. 1997, 59, 577-582. [CrossRef]

36. Çok, İ.; Yelken, Ç.; Durmaz, E.; Üner, M.; Sever, B.; Satır, F. Polychlorinated Biphenyl and Organochlorine Pesticide Levels in Human Breast Milk from the Mediterranean city Antalya, Turkey. Bull. Environ. Contam. Toxicol. 2011, 86, 423-427. [CrossRef]

37. Szyrwińska, K.; Lulek, L. Exposure to specific polychlorinated biphenyls and some chlorinated pesticides via breast milk in Poland. Chemosphere 2007, 66, 1895-1903. [CrossRef]

38. Müller, M.H.B.; Polder, A.; Brynildsrud, O.B.; Karimi, M.; Lie, E.; Manyilizu, W.B.; Mdegela, R.H.; Mokiti, F.; Murtadha, M.; Nonga, H.E.; et al. Organochlorine pesticides (OCPs) and polychlorinated biphenyls (PCBs) in human breast milk and associated health risks to nursing infants in Northern Tanzania. Environ. Res. 2017, 154, 425-434. [CrossRef]

39. Mueller, J.F.; Harden, F.; Toms, L.M.; Symons, R.; Furst, P. Persistent organochlorine pesticides in human milk samples from Australia. Chemosphere 2008, 70, 712-720. [CrossRef] 
40. Lignell, S.; Glynn, A.; Aune, M.; Darnerud, P.O.; Bjerselius, R.; Becker, W. Studie of Förstföderskor. Organiskemiljøgifterhos Gravid Ochammande-Del 2: Bröstmjölksnivåersamtkorrelationmellan Serum-Ogbröstmjölksnivåer; National Food Administration: Uppsala, Sweden, 2008.

41. Polder, A.; Thomsen, C.; Lindstrom, G.; Loken, K.B.; Skaare, J.U. Levels and temporal trends of chlorinated pesticides, polychlorinated biphenyls and brominated flame retardants in individual human breast milk samples from Northern and Southern Norway. Chemosphere 2008, 73, 14-23. [CrossRef] [PubMed]

42. Bulut, S.; Akkaya, L.; Gök, V.; Konuk, M. Organochlorine pesticide (OCP) residues in cow's, buffalo's, and sheep's milk from Afyonkarahisar region, Turkey. Environ. Monit. Assess. 2011, 181, 555-562. [CrossRef] [PubMed]

43. Fromberg, G.F.; Granby, K.; Højgård, A.; Fagt, S.; Larsen, J.C. Estimation of dietary intake of PCB and organochlorine pesticides for children and adults. Food Chem. 2011, 125, 1179-1187. [CrossRef]

44. Witczak, A.; Pohoryło, A. The estimation of consumer health risk associated with organochlorine xenobiotics in hard smoked cheese in Poland. J. Environ. Sci. Health B 2015, 50, 595-606. [CrossRef] [PubMed]

45. Willett, K.L.; Ulrich, E.M.; Hites, R.A. Differential toxicity and environmental fates of hexachlorocyclohexane isomer. Environ. Sci. Technol. 1998, 32, 2197-2207. [CrossRef]

46. Klinčić, D.; Herceg Romanić, S.; Sarić, M.; Grzunov, J.; Dukić, B. Polychlorinated biphenyls and organochlorine pesticides in human milk samples from two regions in Croatia. Environ. Toxicol. Pharm. 2014, 37, 543-552. [CrossRef]

47. Ennaceur, S.; Gandoura, N.; Driss, M.R. Distribution of polychlorinated biphenyls and organochlorine pesticides in human breast milk from various locations in Tunisia: Levels of contamination, influencing factors, and infant risk assessment. Environ. Res. 2008, 108, 86-93. [CrossRef]

48. Rai, S.; Dua, V.K.; Chopra, A.K. Bio-monitoring of Persistent Organochlorines in Human Milk and Blood Samples from SubHimalayan Region of India. Bull. Environ. Contam. Toxicol. 2012, 89, 592-597. [CrossRef]

49. Polder, A.; Gabrielsen, G.W.; Odland, J.O.; Savinova, T.N.; Tkachev, A.; Loken, K.B. Spatial and temporal changes of chlorinated pesticides, PCBs, dioxins (PCDDs/PCDFs) and brominated flame retardants in human breast milk from Northern Russia. Sci. Total Environ. 2008, 391, 41-54. [CrossRef]

50. Gebremichael, S.; Birhanu, T.; Tessema, D.A. Analysis of organochlorine pesticide residues in human and cow's milk in the towns of Asendabo, Serbo and Jimma in South-Western Ethiopia. Chemosphere 2013, 90, 1652-1657. [CrossRef]

51. Di Bella, G.; Potortì, A.G.; Lo Turco, V.; Licata, P.; Rastrelli, L.; Dugo, G. Donkey's milk safety: POCs and PCBs levels and infant daily intake. Food Control 2014, 46, 210-216. [CrossRef]

52. Blüthgen, A. Contamination of milk from feed. Bull. IDF 2000, 356, 43-47.

53. Behrooz, R.D.; Sari, A.E.; Bahramifar, N.; Ghasempouri, S.M. Organochlorine pesticide and polychlorinated biphenyl residues in human milk from the Southern Coast of Caspian Sea, Iran. Chemosphere 2009, 74, 931-937. [CrossRef] [PubMed]

54. Azeredo, A.; Torres, J.P.M.; de Freitas Fonseca, M.; Lailson Britto, J.; Rodrigues Bastos, W.; Azevedo e Silva, C.E.; Cavalcanti, G.; Ornellas Meire, R.; Sarcinelli, P.N.; Claudio, L.; et al. DDT and its metabolites in breast milk from the Madeira River basin in the Amazon, Brazil. Chemosphere 2008, 73, 246-251. [CrossRef] [PubMed]

55. Mamontova, E.A.; Tarasova, E.N.; Mamontov, A.A. PCBs and OCPs in human milk in Eastern Siberia, Russia: Levels, temporal trends, and infant exposure assessment. Chemosphere 2017, 148, 239-248. [CrossRef]

56. Dimitriadou, L.; Malarvannan, G.; Covaci, A.; Iossifidou, E.; Tzafettas, J.; Zournatzi-Koiou, V.; Kalantzi, O.I. Levels and profiles of brominated and chlorinated contaminants in human breast milk from Thessaloniki, Greece. Sci. Total Environ. 2016, 539, 350-358. [CrossRef]

57. Minh, N.H.; Someya, M.; Minh, T.B.; Kunisue, T.; Iwata, H.; Watanabe, M. Persistent organochlorine residues in human breast milk from Hanoi and Hochiminh City, Vietnam: Contamination, accumulation kinetics and risk assessment for infants. Environ. Pollut. 2004, 129, 431-441. [CrossRef]

58. Sudaryanto, A.; Kunisue, T.; Kajiwara, N.; Iwata, H.; Adibroto, T.A.; Hartono, P.; Tanabe, S. Specific accumulation of organochlorines in human breast milk from Indonesia: Levels, distribution, accumulation kinetics and infant health risk. Environ. Pollut. 2006, 139, 107-117. [CrossRef]

59. Benbrook, C.M. Organochlorine residues pose surprisingly high dietary risks. J. Epidemiol. Community Health $2002,56,822$. [CrossRef]

60. Darnerud, P.O.; Atuma, S.; Aule, M.; Bjerelius, R.; Glynn, A.; Petersson Grawe, K.; Becker, W. Dietary intake estimations of organohalogen contaminants (dioxins, PCB, PBDE and chlorinated pesticides, e.g., DDT) based on Swedish market basket data. Food Chem. Toxicol. 2006, 44, 1597-1606. [CrossRef]

61. Chung, S.W.C.; Kwong, K.P.; Yau, J.C.W. Dietary exposure to DDT of secondary school students in Hong Kong. Chemosphere 2008, 73, 65-69. [CrossRef] [PubMed]

62. Dz, U. Regulation of the Minister of Health of 16 September 2010 on Foodstuffs for Particular Nutritional Purposes. 2010; 180, p. 1214. Available online: http:// prawo.sejm.gov.pl/isap.nsf/DocDetails.xsp?id=WDU20101801214 (accessed on 21 May 2017).

63. Dz, U. Announcement of the Minister of Health of 16 June 2015 on the Publication of a Uniform Text of the Regulation of the Minister of Health on Foodstuffs for Particular Nutritional Uses. 2015; p. 1026. Available online: http://prawo.sejm.gov.pl/isap. nsf/DocDetails.xsp?id=WDU20150001026 (accessed on 15 July 2017). 